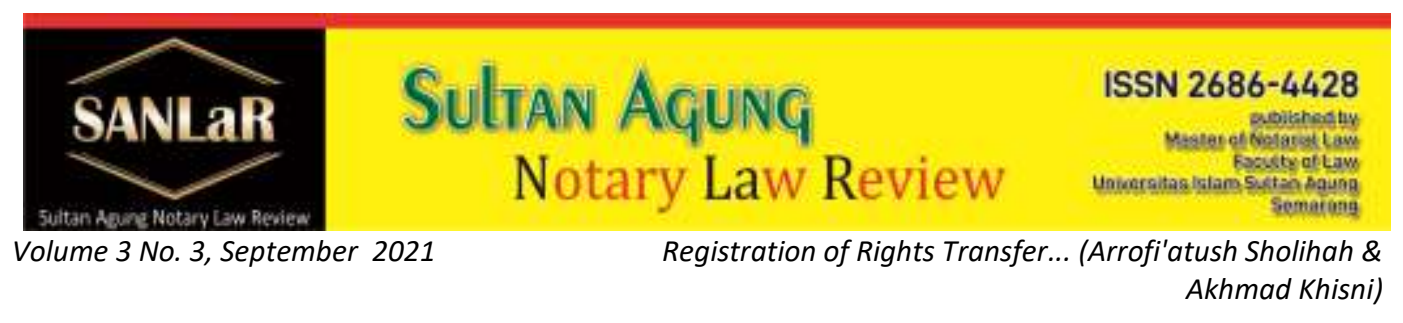

\title{
Registration of Rights Transfer of Land Due to Instruction Related to Development of Collective Rights Sharing (APHB)
}

\author{
Arrofi'atush Sholihah ${ }^{*}$ and Akhmad Khisni ${ }^{* *}$ \\ *) Faculty of Law, Universitas Islam Sultan Agung (UNISSULA) Semarang, E-mail: \\ arrofiaas.26@gmail.com
}

\begin{abstract}
The results of research and discussion suggest that the transfer of rights due to inheritance occurs at the time of a person's death. In a sense, that since then the heirs became the new rights holders. As to who is the heir is stipulated in the applicable civil law. If the heirs are more than one person, and the heirs agree to appoint one of the heirs as the rights holder who will be listed in the certificate by making an inheritance certificate and an affidavit of the heirs, then by PPAT will be made APHB as the basis for the transfer of rights with the approval of all heirs. The purpose of this research is to know the process of implementing the registration of transfer of rights due to inheritance related to $A P H B$, Legal consequences for the registration of land rights transfer due to inheritance related to $A P H B$ and the creation of $A P H B$ Deed. This study uses empirical juridical approach method with data collection techniques through primary data and secondary data. To collect primary data is done with field research using interviews. While the secondary data is obtained by reviewing primary legal materials and secondary legal materials, which are then analyzed using qualitative analysis techniques and interpreted logically and systematically which are then concluded.
\end{abstract}

Keywords: Registration; Rights; Transfer; Instruction; Development; Collective.

\section{Introduction}

Land is an important part of humans, because every human activity is always related to land. The role of land as a source of prosperity, prosperity and life. In addition, land has a close relationship with humans because land has economic value for human life and can produce natural resources for many people. 
To create the prosperity and welfare of the people as desired by the Indonesian people, problems related to the use, ownership, and transfer of land rights require special attention in the legislation. The basic foundation for the Indonesian government and people to regulate policies in the land sector is contained in Article 33 paragraph (3) of the 1945 Constitution which states:

"Earth and water and the natural resources contained therein are controlled by the state and used for the greatest prosperity of the people."

Guarantee of legal certainty regarding the control or transfer of land rights by a person, which is obtained from inheritance is the transfer of a land right to another person. What is meant by the researcher here is the ownership of land rights obtained from the heir to the heirs. So the transfer of rights over means that the subject of rights, namely heirs and heirs, needs to be registered for the transfer of rights to obtain legal certainty of ownership of land rights. To guarantee legal certainty of ownership of inherited land rights, especially in the transfer of rights to inherited land, it is necessary to regulated in a statutory regulation, specifically regulated in the Basic Agrarian Law (UUPA).

The transfer of ownership rights to land is regulated in Article 20 paragraph (2) of Law Number 5 of 1960 concerning Basic Agrarian Provisions (UUPA), namely property rights can be transferred and transferred to other parties have been died. Then the rights themselves become transferred to their heirs. Meanwhile, the meaning of the word "transferred" is that the transfer of ownership rights to land can occur due to legal actions and legal events. The transfer of property rights due to legal actions can occur if the holder of the property rights on the land deliberately transfers the rights he holds to another party. Meanwhile, the transfer of ownership rights to land due to legal events occurs when the holder of property rights to land dies, ${ }^{1}$

Every change in land rights must be registered both changes in physical data and juridical data, including changes in land ownership due to the death of the owner.

The transfer of inheritance rights in the form of land is proven through a certificate of inheritance made by the heirs, known or legalized by the authorized official, then registration is carried out at the local Land Office so that it is recorded in the land book regarding the new right holder, namely on the name of the heir, this is important to do so that it has legal force. In accordance with the provisions of Article 42 paragraph (3) and paragraph (4) of Government

\footnotetext{
1 Mijazin Fahmi, Factor Pendukung Dan Penghambat Peralihan Hak Atas Tanah Karena Pewarisan, http://etd.etrinds.ums.ac.id, Accessed On February 9, 2021 at 22:12
} 
Regulation Number 24 of 1997 it is regulated on the procedure for the transfer of rights due to inheritance.

The task of registering the transfer of existing rights is handled by the National Land Agency. By looking at the provisions of Article 20 of the Basic Agrarian Law, the registration of land rights is very important, because the land that has been registered will get a Certificate of Land Ownership which is called a certificate. This certificate is a land right that has permanent legal force and certainty. Registration of land rights due to inheritance must be carried out by the holder of land rights who receive the inheritance.

When a person dies, this creates a legal consequence, namely how the management and continuation of the rights and obligations as a result of a legal event due to the death of a person is regulated by the Inheritance Law. ${ }^{2}$ Broadly speaking, inheritance law is the law that regulates the transfer of rights in the form of property in the form of movable or immovable objects that are given to heirs based on kinship or marital relations. ${ }^{3}$

In its implementation in Semarang City, the registration of the transfer of rights to one of the heirs based on the inheritance distribution deed made by a notary or private deed which is carried out simultaneously during the inheritance process cannot be used as the basis for the transfer of land rights. This is because the registration of the transfer of rights due to inheritance is carried out by first inheriting on behalf of all heirs, giving rise to joint ownership. After that, when the rights holders want to divide the rights to one or several people, it is done by making a deed of sharing rights together by PPAT $^{4}$.

The deed of sharing of joint rights is a deed that contains an agreement between the holders of joint rights regarding the distribution of joint rights. While the distribution of joint rights is a legal act carried out by joint rights holders with the aim of ending joint ownership of the rights of each joint right holder. ${ }^{5}$ So the distribution of joint rights can be carried out in advance of deliberation among the joint rights holders regarding the parts obtained by each.

\footnotetext{
${ }^{2}$ Hasballah Thaib dan Syahril Sofyan, 2014, Teknik Pembuatan Akta Penyelesaian Warisan Menurut Hukum Waris Islam di Indonesia, Citapustaka Media, Medan, p. 2.

${ }^{3}$ Zainuddin Ali, 2010, Pelaksanaan Hukum Waris di Indonesia, Sinar Grafika, Jakarta, p. 43

${ }^{4}$ A Chuasanga, Ong Argo Victoria. (2019). Legal Principles Under Criminal Law in Indonesia Dan Thailand, Jurnal Daulat Hukum, Vol 2, No 1 (2019) http://jurnal.unissula.ac.id/index.php/RH/article/view/4218 see Deen, Thaufiq., Ong Argo Victoria \& Sumain. (2018). Public Notary Services In Malaysia. JURNAL AKTA: Vol. 5, No. 4, 10171026. Retrieved from http://jurnal.unissula.ac.id/index.php/akta/article/view/4135

${ }^{5}$ Renny Listianita, "Peran PPAT Dalam Proses Pembagian Hak Bersama Tanah Warisan di Surakarta", Jurnal Reportorium, Edition 3 January-June 2015, Faculty of Law, Universitas Negeri Surakarta, Surakarta, p. 110.
} 
In the distribution, the joint rights holders do not have to fully get a share. Sometimes the individual rights holders are one or several of the joint rights holders in accordance with the agreement stated in the joint rights distribution deed.

The registration of the transfer of land rights based on the deed of distribution of joint rights can be carried out if at the time of registering the rights of the heirs the heirs only include a certificate of inheritance as proof of heirs and there has been no distribution of inheritance, resulting in joint ownership of land rights. Then when the land is to be divided, the distribution is stated in the deed of sharing of joint rights depending on the agreement of all the heirs.

PP 24/1997 explicitly regulates the procedures and conditions specified in the event of a process of transferring land rights. Therefore, from the above description to obtain an overview of the implementation of PP 24/1997 concerning Land Registration, especially the Transfer of Rights due to inheritance in the working area of Semarang City. So that the author wants to discuss more deeply about how is the process of transferring rights due to inheritance, and what are the legal consequences.

\section{Research Methods}

This study uses an empirical juridical approach with data collection techniques through primary data and secondary data. To collect primary data conducted by field research using interviews. While secondary data is obtained by examining primary legal materials and secondary legal materials, which are then analyzed using qualitative analysis techniques and interpreted logically and systematically which then draws conclusions.

\section{Result and Discussion}

\subsection{The Process Of Implementation Of Registration Of Transfer Of Rights To Land Due To Instruction Related To The Share Of Collective Rights}

The transfer of rights due to inheritance occurs by law when the right holder in question dies. In the sense that since then the heirs have become the new right holders.

From the description above, it can be seen that there has been an automatic transfer of rights from the heir to his heirs, the changes that will arise are in the juridical data in the rights base which is the object of inheritance. The registration of the transfer of land rights must be carried out if there is a change in physical and juridical data, this is in the context of providing legal protection to the heirs and for the sake of order in the administration of land registration, so 
that the data stored and presented always shows the current state. Unlike the provisions of Government Regulation number 10 of 1961, the period for registration is not stipulated, if it is done within six months from the date of death of the testator.

Documents that prove the existence of land rights to the beneficiary are needed, because the registration of the transfer of rights can only be carried out after the first registration of the right in question is carried out in the name of the beneficiary. This is explained in the Elucidation of Article 42 paragraph (2) of PP Number 24 of 1997. From the provisions of Article 42 paragraph (2) of Government Regulation Number 24 of 1997 above, then:

1. The heirs must show proof of rights in the form of written evidence, witness statements and or statements in question, the content of which is deemed sufficient by the Adjudication committee or the Head of the Land Office to register rights, rights holders and the rights of other parties that burden them;

2. A certificate stating that the land parcel in question has not been certified from the Land Office, or for land located in an area far from the location of the Land office, from the right holder in question, supported by the Village Head,

3. Based on the data in points 1 and 2 above, an inheritance deed is then made by the Land Deed Making Officer.

If the beneficiary consists of one person, the registration of the transfer of rights is carried out to that person based on a letter of evidence as the heir concerned. However, if the beneficiary is more than one person and when the transfer of rights is registered accompanied by a deed of distribution of inheritance which contains a statement that the right to land or ownership rights to a particular apartment unit falls to a certain beneficiary, the registration of the transfer of rights is carried out directly to the beneficiary who concerned, based on the letter of evidence as the heir and the deed of distribution of the inheritance, without other evidence of the transfer of rights, for example the PPAT deed, the deed of distribution of inheritance can be made in the form of a deed under the hands of all heirs witnessed by 2 witnesses or with a deed Notary Public. ${ }^{6}$

Based on the provisions in Article 51 of Government Regulation Number 24 of 1997 concerning land registration, it is expressly obligated to make a PPAT deed, namely a deed of sharing of joint rights in the event of an inheritance event where the heirs agree on the distribution of the joint rights.

If the heirs of the joint rights holder have agreed to divide the joint rights into their respective rights so that they are no longer the joint rights of a certificate,

\footnotetext{
${ }^{6}$ Boedi Harsono, Hukum Agraria Indonesia, Sejarah Pembentukan Undang-Undang Pokok Agraria, Isi Dan Pelaksanaannya, Djambatan, p.520.
} 
in the collective agreement that each party will receive a share according to the agreement or will be given to one of the heirs, which will be stated in the deed made by the PPAT appointed by the parties.

Based on the results of the author's interview with $\mathrm{Hj}$. Ria Kusumawardhani Bachelor of Law, Master of Notary, as Notary/PPAT Semarang City, with reference to the provisions of Government Regulation No. 24 of 1997 concerning Land Registration that the basis for the transfer of land rights originating from inheritance which becomes joint rights is the making of a deed of reparation of joint rights which made by the PPAT as the basis for the transition used to register the transfer of rights at the land office, because the basis for the transfer other than the deed of distribution of joint rights cannot be used as the basis for the transfer of a joint right to the land office. ${ }^{7}$ Then the deed that has been registered at the local Land Office in accordance with the provisions of Government Regulation Number 24 of 1997 concerning Land Registration no later than one week after the making of the deed.

If at the request of the right holder in question (or his proxies) agrees to divide the joint rights into their respective rights, then one parcel of land that has been registered can be completely divided into several parts, each of which is a new midwife unit with the same legal status. with the original plot of land. For each plot of land, a measuring document, land book, and certificate are made to replace the measuring document, land book, and certificate of origin. ${ }^{8}$

Every legal action that will be carried out on land objects that are still joint rights must use a deed made by the authorized PPAT. For example, the heirs agree to divide the joint rights in the inheritance land into the property of each heir according to the agreement, then the experts can go directly to PPAT to ask for a deed of distribution of joint rights according to the agreement of the parties, by bringing documents such as:

1. Certificate of Inheritance that has been known to the district head and village head

2. Certificate of death

3. Original certificate

4. Heir's family card

5. ID card applicants

Based on the existing documents, the PPAT can immediately make the deed, thus the joint rights that were still one will be divided into the rights of each heir according to the agreement of the heirs.

${ }^{7}$ Hj. Ria Kusumawardhani SH, M.Kn, Interview, Notary/PPAT Semarang City, 13 July 2021

${ }^{8}$ Boedi Harsono, Op.cit, p. 525 
The deed of sharing rights together is one of the deeds that is used as the basis for the transfer of rights in accordance with Article 51 PP 24/1997. Broadly speaking, the process of transferring rights due to inheritance using a deed of sharing rights is as follows:

1. Registration at the Land Office by attaching a letter of application and other documents such as:

a. Original certificate

b. Certificate of death

c. Inheritance certificate, because the transfer of rights discussed is for the original indigenous people, it is enough with a certificate of inheritance witnessed by 2 witnesses and confirmed by the Camat and Lurah.

d. Power of attorney (if the applicant is not an heir)

e. Identity of the heirs.

f. SPPT PBB for the year

g. Proof of deposit BPHTB.

After all documents are complete, the applicant immediately registers with the Land Office by paying a registration fee in accordance with the provisions stipulated in the Decree of the Head of the National Land Agency 1 of 2005.

Then if all the documents have been declared complete, the head of the Land Office must complete the administrative process for the data selection at the land office at the latest, but in practice the process still exceeds the allotted time, this is due to many obstacles in the field. which results in delays in the administrative process at the Land Office, for example, obstacles in the field in carrying out measurements, the determination of specified boundaries, not yet constraints within the land office itself, for example the Land Book from the certificate to be processed is still used for other land administration processes, so that matters. The above are often complaints from applicants for the transfer of rights to the Land Office, Actually, the above constraints based on the author's experience can be avoided as long as there is awareness and a strong will from the Land Office itself to carry out procedures according to existing instructions, so that the objectives and principles of land registration as stated in PP 24/1997 can be achieved.

\subsection{Legal Consequences On Registration Of Transfer Of Rights To Land Due To Instruction Related To Joint Rights Sharing Deed}

In relation to inheritance, it means that inheritance is the transfer of property rights to another party because the owner dies. The transfer of property rights occurs for the sake of law, meaning that with the death of the owner, the inheritance expert obtains property rights, the transfer of inheritance rights in 
the form of land through an inheritance certificate made by the heirs, is known or ratified by the authorized official.

With the death of a person, immediately all rights and obligations of inheritance are transferred to the heirs (saisine rights). Saisine rights mean the heirs by law obtain the wealth of the testator without demanding surrender. With regard to Saisine rights, it is also known as heridity petition, which is the case for the heir to sue, specifically with regard to inheritance.

In case of re-registration name due to inheritance where there is more than one heir, and the heirs agree to appoint one of the heirs as the right holder which will later be listed in the land certificate, in the process of transferring the rights it must be accompanied by making APHB.

The deed of sharing rights together is an authentic deed. So that if in the future there is a lawsuit against the deed made, the parties must be able to prove themselves against the lawsuit. This means that if the heirs deny the deed they have made, then they must prove themselves against the untruth of the deed. An authentic deed has perfect evidentiary power, if there is a party who sues then he must prove his claim.

As for the possibilities of someone relinquishing the right in inheritance for APHB, it is due to avoid disputes in the future. The heirs who relinquish the right will usually provide certain conditions, namely by asking for a sum of money to the heirs of the recipient of the right, or it could be if the inheritance is large or consists of several parcels of land, the heirs will divide/take their respective shares so that in the certificate it is only recorded that only one heir is recorded so that in the future it will not cause disputes in the future.

\section{Closing}

The implementation of the registration of the transfer of ownership rights to land due to inheritance if the ownership rights to land due to inheritance can be carried out by making a certificate of inheritance which explains who is the heir. Then make a statement of heirs explaining appointing one of the heirs as the right holder or dividing the rights equally among each heir. The certificate of inheritance and the statement of heirs must be known by the RT, RW, village head and district head. Then the registration of the transfer of rights must be made a deed called APHB by PPAT as one of the requirements for the process of transferring the rights. By making a deed of sharing rights together. The legal consequences of making APHB in the registration process for the transfer of rights due to inheritance are: a. For the right beneficiary: will be the only right holder whose name will be listed on the certificate. b. For those who relinquish rights: they no longer have rights to property rights that were previously owned together. 


\section{References}

Journals:

[1] A Chuasanga, Ong Argo Victoria. (2019). Legal Principles Under Criminal Law in Indonesia Dan Thailand, Jurnal Daulat Hukum, Vol 2, No 1 (2019) http://jurnal.unissula.ac.id/index.php/RH/article/view/4218

[2] Deen, Thaufiq., Ong Argo Victoria \& Sumain. (2018). Public Notary Services In Malaysia. JURNAL AKTA: Vol. 5, No. 4, 1017-1026. Retrieved from http://jurnal.unissula.ac.id/index.php/akta/article/view/4135

[3] Renny Listianita,"Peran PPAT Dalam Proses Pembagian Hak Bersama Tanah Warisan di Surakarta", Jurnal Reportorium, Edisi 3 January-June 2015, Fakultas Hukum Universitas Negeri Surakarta, Surakarta

Books:

[1] Ali, Zainuddin, 2010, Pelaksanaan Hukum Waris di Indonesia, Sinar Grafika, Jakarta

[2] Harsono, Boedi. 1997. Hukum Agraria Indonesia, Sejarah Pembentukan Undang-Undang Pokok Agraria, Isi Dan Pelaksanaannya. Jakarta: Djambatan.

[3] Hasballah Thaib dan Syahril Sofyan, 2014, Teknik Pembuatan Akta Penyelesaian Warisan Menurut Hukum Waris Islam di Indonesia, Citapustaka Media, Medan.

Internet:

Mijazin Fahmi, Factor Pendukung Dan Penghambat Peralihan Hak Atas Tanah Karena Pewarisan, http://etd.etrinds.ums.ac.id, accessed on 9 February 2021 